\title{
Parasites for filth fly control on dairies
}

\author{
Jeffery A. Meyer $\square$ BradleyA. Mullens $\square$ Tracy L. Cyr $\square$ Clare Stokes
}

\section{Short-term releases of commercial fly parasites on dairies did not im- prove overall fly control. Naturally occurring fly parasites were found to be significant mortality factors.}

Stable flies (Stomoxys calcitrans [L.]) and house flies (Musca domestica L.) are economically important pests on California dairies, but each inflicts damage in its own way. The stable fly sucks blood from dairy cows, causing direct losses in production. These losses may be correlated with altered cow behavior during periods of greater fly activity. Chemical control of adult stable flies involves applying insecticides directly to the cows or, to a lesser extent, to the dairy premises. However, in most cases the treatment is marginally effective, and it is seldom practiced in the field.

House flies become economically important to the dairy producer when excessive fly populations prompt neighbors to complain. The regulatory agencies (vector control districts, county environmental health agencies) responsible for enforcing fly control ordinances can issue citations if excessive fly development continues. House flies on California dairies are sometimes controlled by Pest Control Operators (PCOs) who spray the dairies with residual and space insecticides. Insecticides have been used extensively to control house flies on dairies, and UC researchers have documented high levels of insecticide resistance in the more concentrated dairying areas of southern California (Riverside and San Bernardino counties).

Small wasps in the genera Muscidifurax and Spalangia, although harmless to humans, parasitize fly pupae and can be produced in the laboratory in sufficient quantities for field release. Researchers in several areas of the United States have evaluated the periodic release of fly parasites for bio- logical control of stable and house flies in confinement livestock facilities, but little is known about the efficacy of commercially available parasites. Commercial fly parasites are readily available; California alone is home to at least 11 suppliers. By implementing more biological control on confinement dairies, farmers should be able to help reduce the selection pressure for insecticide resistance.

To make the change, though, dairy farmers must know whether the parasites are effective. Our study evaluated the shortterm impact of sequential releases of commercial fly parasites on pupal parasitism and adult population levels of house and stable flies on southern Califonia dairies.

\section{Study sites, evaluation methods}

Four study dairies were selected in the Chino Basin of western Riverside County: two dairies, MO and DG, received monthly releases of commercial fly parasites, and two dairies, JO and DJ, served as controls. For one treatment, we released three different parasite species on a 550-cow dairy (MO). The species composition was dictated by the insectary, with release times and parasite quantity managed by a $\mathrm{PCO}$.

The PCOalso conducted routine chemical fly control with residual and space sprays during this period. Fly parasites had been released on the MO dairy since 1985 , but no records of species composition or release amounts were available for 1985 . The control dairy for this treatment was the 600-cow JO dairy, which practiced no chemical or commercial fly control aside from setting out small amounts of methomyl-treated fly bait.

The second treatment involved monthly releases of fly parasites on the 700-cow DG dairy. These parasites were acquired from a different insectary, and about 350,000 per month were released by UC personnel from April through October. We evaluated about 200 pupae from each shipment for emer-

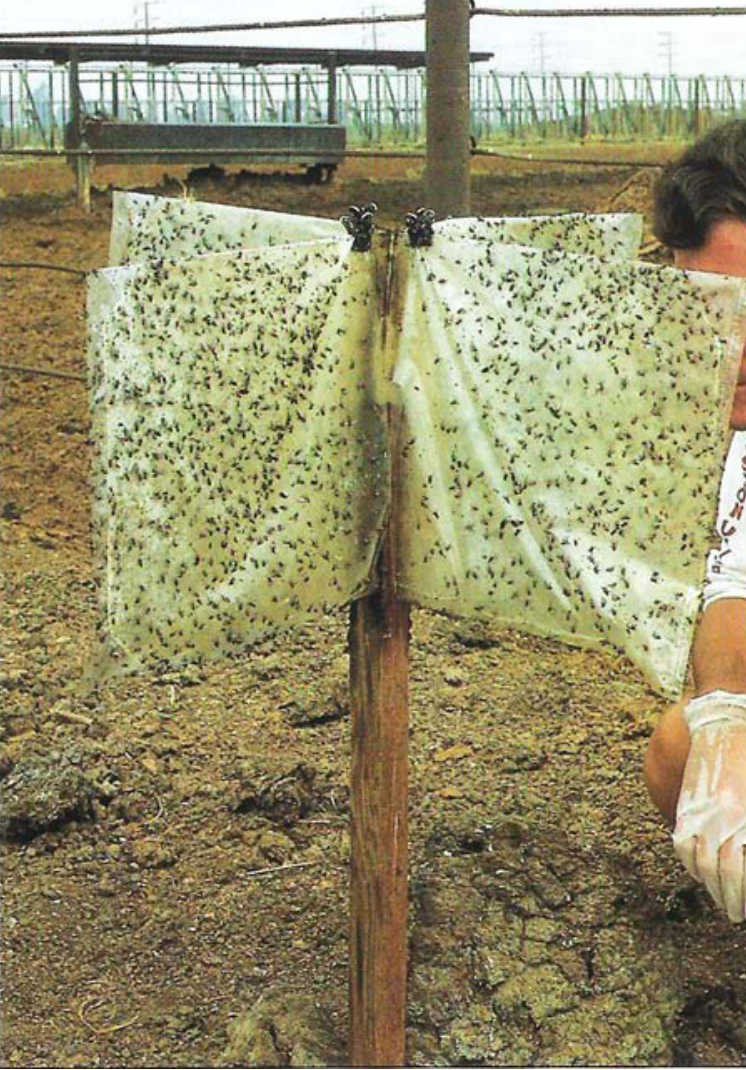

Three sticky traps like this one were placed at each test dairy. Researchers tallied the captured flies once a week.

gence and species composition by holding one group of pupae in the laboratory and a second group in a shaded area on the DG dairy. The parasite species composition and emergence rate of each shipment are shown in tables 1 and 2 . The control dairy for this treatment was the DJ dairy, which milked approximately 1,400 cows and practiced no other forms of fly control.

We evaluated the effectiveness of each parasite treatment by three methods. First, we monitored adult stable and house flies on all four dairies. Three sticky traps were placed at strategic locations around each dairy. The caught flies were counted and the traps re-coated weekly. Trapping began early in April and continued through October.

Second, we collected house and stable fly pupae from fly breeding sites on each dairy. Dairies were scouted during each weekly visit to locate the five to seven major fly breeding sites. We collected 50 to 100 fly pupae from each of these sites, when possible. Pupae were held individually in the laboratory and monitored for parasite emergence.

Third, we evaluated parasite activity using a sentinel bag, a small bag constructed of fiberglass screening and containing 20 house fly pupae less than 24 hours old. Parasites can enter these bags easily to parasitize the fly pupae. Ten bags were buried 1 to 2 


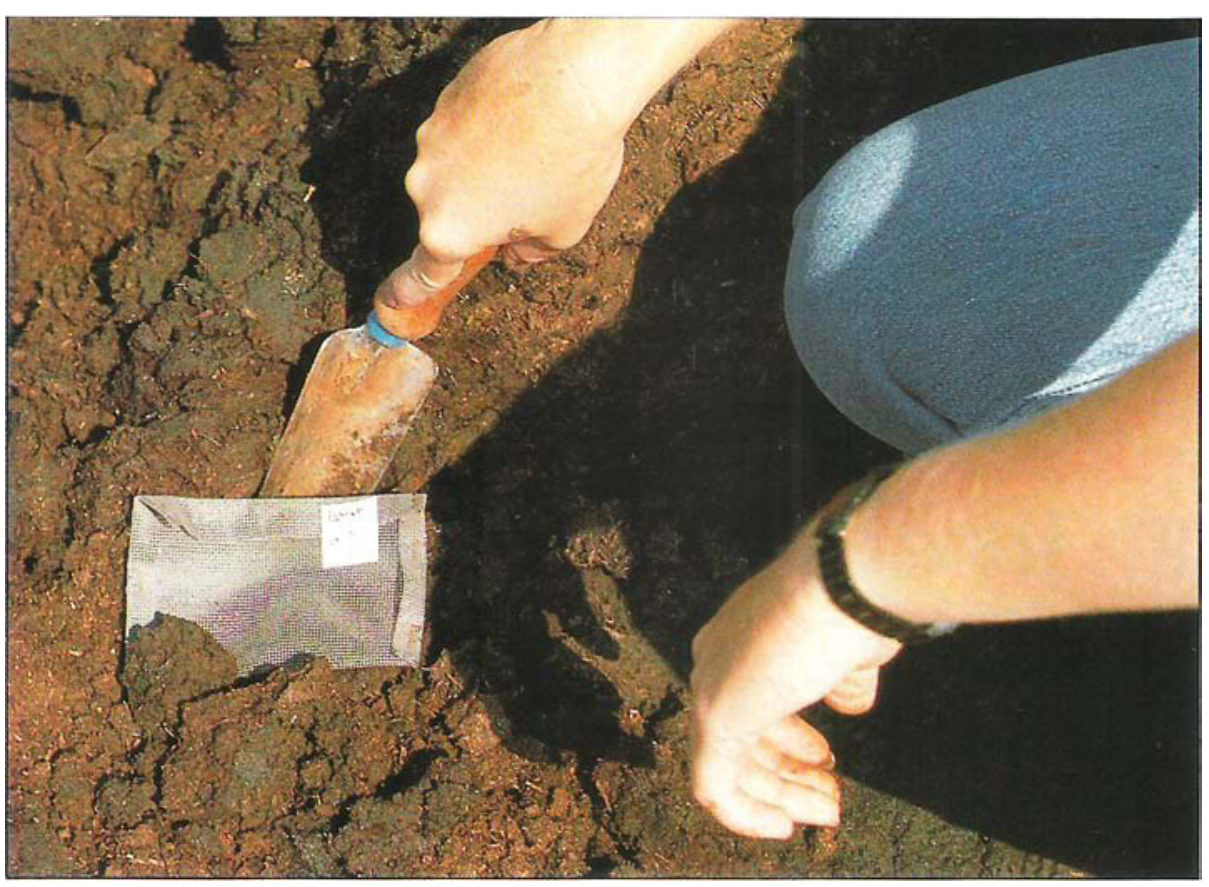

Fiberglass sentinel bags, each holding 20 young house fly pupae, were buried in fly-breeding sites on the dairies. The mesh openings were large enough to admit parasites but too small to allow the pupae to escape.

inches deep in fly breeding sites on each dairy and left in place for 1 week. The bags were then recovered, and the pupae were held in the laboratory to monitor parasite emergence.

\section{Adult fly populations}

Neither parasite treatment appeared to affect adult stable or house fly populations. The seasonal intensity of stable fly activity was similar on all four dairies, with a large

peak in May and early June and a smaller peak in late October. Seasonal intensity of adult house fly activity was also similar on the release and control dairies.

Combining chemical and biological methods did not appear to suppress adult house fly populations on the MO dairy (PCO treatment), as compared to the JO dairy, its control. However, marked differences in insecticide resistance among dairies in earlier UC trials were correlated with

TABLE 1. Summary of parasite species and approximate quantities released on MO dairy (Pest Control Operator) treatment during 1986-87

\begin{tabular}{ccccc}
\hline \hline Year & Species* & $\begin{array}{c}\text { Month(s) of } \\
\text { release }\end{array}$ & $\begin{array}{c}\text { Percent of each } \\
\text { species/release }\end{array}$ & $\begin{array}{c}\text { Total no. } \\
\text { released/mo. }\end{array}$ \\
\hline \multirow{2}{*}{1986} & MZ/SE & Jan.-Apr. & $\%$ & 200,000 \\
& SE & May-Dec. & $50 / 50$ & 10,000 \\
1987 & MZ/SE & Jan.-Mar. & 100 & 200,000 \\
& AE/MRL & Apr. & $50 / 50$ & 200,000 \\
& MZ/MRL & May-Oct. & $25 / 75$ & 10,000 \\
& MZ/MRL/SE & Nov.-Dec. & $50 / 50$ & 200,000 \\
\hline
\end{tabular}

${ }^{*} \mathrm{MZ}=$ Muscidifurax zaraptorKogan and Legner; $\mathrm{SE}=$ Spalangia endius Walker; $\mathrm{MRL}=$ Muscidifurax raptorellus Kogan \& Legner.

TABLE 2. Relative abundance of parasite species from monthly insectary shipments of parasitized fly pupae held under laboratory and field conditions and released on DG dairy during 1987

\begin{tabular}{|c|c|c|c|c|c|c|c|}
\hline \multirow[b]{2}{*}{ Month } & \multicolumn{5}{|c|}{ Percentage of each species ${ }^{\star}$} & \multicolumn{2}{|c|}{ Percentage emergence } \\
\hline & MZ & MR & PV & NV & SE & Laboratory & Field \\
\hline April & 25.0 & 8.7 & 0.0 & 66.3 & 0.0 & 53.0 & 32.0 \\
\hline May & 0.0 & 0.0 & 100.0 & 0.0 & 0.0 & 60.0 & 65.0 \\
\hline June & 91.6 & 0.0 & 6.7 & 1.7 & 0.0 & 79.0 & 69.0 \\
\hline Julyt & & & & & & 21.0 & 49.0 \\
\hline August & 69.9 & 11.6 & 13.9 & 4.6 & 0.0 & 30.0 & 39.0 \\
\hline September & 67.2 & 4.0 & 13.9 & 13.9 & 1.0 & 61.0 & 62.0 \\
\hline October & 58.7 & 5.5 & 24.4 & 10.9 & 0.5 & 49.0 & 29.0 \\
\hline Mean & & & & & & 50.4 & 49.3 \\
\hline
\end{tabular}

"Percentage of total of each species: $\mathrm{MZ}=$ Muscidifurax zaraptor, MR = Muscidifurax raptor, PV = Pachycrepoideus vindemiae; $\mathrm{NV}=$ Nasonia vitripennis; $\mathrm{SE}=$ Spalangia endius.

tData for species composition of July parasite shipment were unavailable.

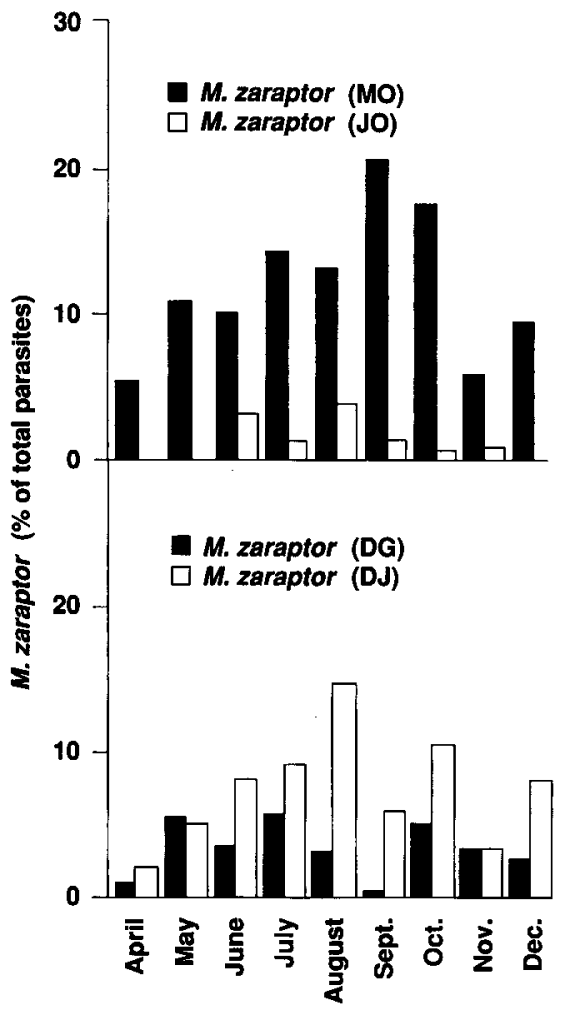

Fig. 1. Monthly recovery of Muscidifurax zaraptorfrom field-collected house fly pupae on parasite-release dairies (MO and DG) and control dairies (JO and DJ).

insecticide use. These differences suggest that house fly subpopulations probably exist on individual dairies. Dairies in the region are generally less than $0.5 \mathrm{~km}$ apart, and adult flies commonly move between dairies. Such large-scale fly dispersal from one dairy to another could obscure the effectiveness of control, regardless of the methods used.

\section{Field-collected fly pupae}

Parasite releases by the $\mathrm{PCO}$ and ourselves had no apparent impact on the overall level of parasitism on field-collected stable and house fly pupae (table 3 ). The parasitism percentage did not significantly exceed those of controls for either species collected from the treated dairies. Because the MO dairy had the highest parasitism rate of the four dairies studied, the PCO's chemical treatments apparently did not inhibit parasite activity. The mean seasonal parasitism of field-collected pupae was remarkably similar for the two fly species (17 to $23 \%$ ), regardless of site or treatment.

The species composition of parasites recovered from field-collected fly pupae is another indication of the impact of parasite releases. Spalangia endius releases on the MO dairy did not increase that parasite's prevalence on field-collected stable or house fly pupae (table 3). Significantly more S.endius were recovered from stable fly pupae on the DG dairy, but the recovery percentage did not correspond to the extremely low num- 
TABLE 3. Relative abundance of the major fly parasite species recovered from field-collected stable and house fly puparia as influenced by monthly releases of fly parasites

\begin{tabular}{|c|c|c|c|c|c|c|c|c|}
\hline \multirow[b]{2}{*}{ Host } & \multirow[b]{2}{*}{ Dairy } & \multirow[b]{2}{*}{ Treatment } & \multicolumn{5}{|c|}{ Percentage of total parasites recovered $( \pm \mathbf{S D})^{*} \dagger$} & \multirow{2}{*}{$\begin{array}{c}\text { Percentage total } \\
\text { parasitism } \\
( \pm \mathrm{SD})\end{array}$} \\
\hline & & & SE & sc & SN & MR & $\mathbf{M Z}$ & \\
\hline \multirow[t]{2}{*}{ Stable fly } & $\begin{array}{l}\text { MO } \\
\text { JO }\end{array}$ & $\begin{array}{l}\text { PCO } \\
\text { Control }\end{array}$ & $\begin{array}{l}26.7(33.8) a \\
32.5(37.9) a\end{array}$ & $\begin{array}{l}28.5(37.7) a \\
24.1(34.2) a\end{array}$ & $\begin{array}{l}12.2(19.4) \mathrm{a} \\
11.3(24.8) \mathrm{a}\end{array}$ & $\begin{array}{l}4.9(13.7) \mathrm{a} \\
7.2(19.3) \mathrm{a}\end{array}$ & $\begin{array}{l}4.4(17.0) \mathrm{a} \\
0.1(1.2) \mathrm{b}\end{array}$ & $\begin{array}{l}16.8(19.7) a \\
19.9(23.8) a\end{array}$ \\
\hline & $\begin{array}{l}\mathrm{DG} \\
\mathrm{DJ}\end{array}$ & $\begin{array}{l}\text { Parasites } \\
\text { Control }\end{array}$ & $\begin{array}{l}40.6(34.7) a \\
26.3(30.6) b\end{array}$ & $\begin{array}{l}21.2(29.0) \mathrm{a} \\
23.7(34.7) \mathrm{a}\end{array}$ & $\begin{array}{l}11.3(18.5) a \\
19.5(27.4) b\end{array}$ & $\begin{array}{l}8.7(23.1) \mathrm{a} \\
8.1(15.3) \mathrm{a}\end{array}$ & $\begin{array}{l}1.1(6.8) a \\
3.2(16.8) a\end{array}$ & $\begin{array}{l}17.2(16.5) \mathrm{a} \\
22.3(22.8) \mathrm{b}\end{array}$ \\
\hline \multirow[t]{2}{*}{ House fly } & $\begin{array}{l}\mathrm{MO} \\
\mathrm{JO}\end{array}$ & $\begin{array}{l}\text { PCO } \\
\text { Control }\end{array}$ & $\begin{array}{l}14.6(23.9) a \\
27.5(30.3) b\end{array}$ & $\begin{array}{l}17.4(28.1) a \\
29.2(34.7) b\end{array}$ & $\begin{array}{l}34.7(36.3) \mathrm{a} \\
23.0(28.6) \mathrm{b}\end{array}$ & $\begin{array}{l}8.9(17.7) \mathrm{a} \\
6.2(14.8) \mathrm{b}\end{array}$ & $\begin{array}{r}12.5(22.9) \mathrm{a} \\
1.3(5.9) \mathrm{b}\end{array}$ & $\begin{array}{l}23.3(20.1) a \\
18.4(20.4) a\end{array}$ \\
\hline & $\begin{array}{l}\text { DG } \\
\text { DJ }\end{array}$ & $\begin{array}{l}\text { Parasites } \\
\text { Control }\end{array}$ & $\begin{array}{l}26.4(28.7) \mathrm{a} \\
22.0(26.5) \mathrm{a}\end{array}$ & $\begin{array}{l}14.9(25.9) \mathrm{a} \\
18.5(28.0) \mathrm{a}\end{array}$ & $\begin{array}{l}32.4(32.3) \mathrm{a} \\
30.2(32.7) \mathrm{a}\end{array}$ & $\begin{array}{l}7.3(16.0) a \\
6.6(15.2) a\end{array}$ & $\begin{array}{l}3.5(11.1) \mathrm{a} \\
7.9(18.0) \mathrm{b}\end{array}$ & $\begin{array}{l}20.9(20.1) \mathrm{a} \\
22.4(20.4) \mathrm{a}\end{array}$ \\
\hline
\end{tabular}

*Percentage of total of each species: SE = Spalangia endius; SC = Spalangia cameroni; SN = Spalangia nigroaenea; MR = Muscidifurax raptor, MZ = Muscidifurax zaraptor. Other species recovered in small numbers included Aleochara spp., Urolepis rufipes, and various Diapriidae.

†Treatment means for each parasite species followed by a common letter are not significantly different, as determined by a two-sample t-test ( $P>0.05)$.

bers of S. endius we released. Relatively more $M$. zaraptor were recovered from stable and housefly pupae on theMO dairy, but no similar relationship was shown for the DG dairy, which received M.zaraptor as the predominant parasite. In fact, $M$. zaraptor activity on house flies was higher on the DJ dairy (control) than on the DG dairy

\section{Sentinel pupae}

The parasitism percentages of sentinel house fly pupae contrasted markedly with those of field-collected pupae. The MO and DG dairies had significantly higher rates of sentinel parasitism overall than did their controls (table 4). The discrepancy may indicate a sampling bias associated with the sentinel bag system, since no sentinel bags were placed in some representative fly breeding sites on the dairy.

Muscidifurax spp. accounted for only $19.6 \%$ of the parasites from field-collected pupae (table 3 ), compared with $73.2 \%$ of those from sentinel bags (table 4). Spalangia spp. accounted for $74.3 \%$ of the parasites recovered from field-collected house fly pupae and only $20.6 \%$ of those recovered from house fly pupae in sentinel bags. The sentinel pupae may have been more acces- sible to Muscidifurax spp., which are reported to forage closer to the manure surface than Spalangia spp. and may outcompete them in such a situation.

\section{Muscidifurax zaraptor}

The intensity and seasonal distribution of $M$. zaraptor activity were much greater on the MO dairy than on the JO dairy, perhaps because of the PCO's sustained releases for the three previous years (fig. 1). Relative abundance of $M$. zaraptor increased with the house fly density between April and September. Also, the relatively high proportion of parasitism by $M$. zaraptor at this time could have been influenced by reduced Spalangia spp. activity at high temperatures. The activity of $M$. zaraptor measured at the DG dairy was very low, despite the monthly releases. Recovery of $M$. zaraptor at the DJ dairy exceeded that of the other control dairy (JO). However, $M$. zaraptor activity at the DJ dairy never reached the levels measured at the MO dairy.

\section{Conclusions}

Reasons for the apparent ineffectiveness of the releases are undoubtedly many and complex. The species composition of para-

TABLE 4. Species composition and relative abundance of parasites recovered from house fly puparia in sentinel bags, placed in fly breeding sites on four dairies, 1987

\begin{tabular}{|c|c|c|c|c|c|c|c|}
\hline \multirow{2}{*}{\multicolumn{2}{|c|}{ DairyTreatment }} & \multicolumn{5}{|c|}{ Percentage of total parasites recovered $( \pm S D)^{\star} \dagger$} & \multirow{2}{*}{$\begin{array}{c}\text { Percentage total } \\
\text { parasitism } \\
( \pm S D)\end{array}$} \\
\hline & & SE & sc & SN & MR & $M Z$ & \\
\hline $\begin{array}{l}\mathrm{MO} \\
\mathrm{JO}\end{array}$ & $\begin{array}{l}\mathrm{PCO} \\
\text { Control }\end{array}$ & $\begin{array}{l}0.0(0.0) a \\
6.2(20.7) a\end{array}$ & $\begin{array}{l}16.3(36.1) a \\
55.1(47.3) b\end{array}$ & $\begin{array}{l}0.4(2.8) a \\
2.1(12.3) a\end{array}$ & $\begin{array}{l}55.6(47.0) a \\
17.4(38.1) b\end{array}$ & $\begin{array}{r}18.7(37.5) \mathrm{a} \\
8.8(28.8) \mathrm{a}\end{array}$ & $\begin{array}{r}21.6(31.4) \mathrm{a} \\
8.1(17.6) \mathrm{b}\end{array}$ \\
\hline $\begin{array}{l}\text { DG } \\
\text { DJ }\end{array}$ & $\begin{array}{l}\text { Parasites } \\
\text { Control }\end{array}$ & $\begin{array}{l}4.4(19.0) a \\
4.0(18.2) a\end{array}$ & $\begin{array}{r}8.9(26.2) a \\
20.8(36.1) a\end{array}$ & $\begin{array}{l}2.6(13.7) a \\
0.0(0.0) a\end{array}$ & $\begin{array}{l}38.3(43.4) \mathrm{a} \\
27.8(42.9) \mathrm{a}\end{array}$ & $\begin{array}{l}30.7(43.1) \mathrm{a} \\
31.9(44.6) \mathrm{a}\end{array}$ & $\begin{array}{l}23.7(20.9) \mathrm{a} \\
10.9(24.2) \mathrm{b}\end{array}$ \\
\hline
\end{tabular}

*Percentage of total of each species: SE = Spalangia endius; $S C$ = Spalangia cameroni; SN = Spalangia nigroaenea; MR = Muscidifurax raptor, $\mathrm{MZ}=$ Muscidifurax zaraptor.

†Treatment means for each parasite species followed by a common letter are not significantly different, as determined by a two sample t-test $(P>0.05)$.

sites released on the DG dairy was somewhat irregular. However, $M$. zaraptor has been shown to cause significant parasitism in both house and stable flies when parasite populations have been natural or manipulated. Also, successful results have to be weighed in terms of the time frame and evaluation methodology used to determine parasitism rates, species, strains, and numbers of parasites. The practical way to measure the success of commercial fly parasites on a confinement dairy is by the reduction in the adult fly population, which is particularly difficult to assess with other dairies close by.

Muscidifurax zaraptor releases on the MO dairy may have contributed to that species' relative abundance, but overall parasitism was not affected. The releases had no demonstrated effect on the DG dairy. Muscidifurax zaraptor had been released on the MO dairy for at least 2 (possibly 3 ) consecutive years, as opposed to only 7 months on the DG dairy. It may be necessary to release parasites for several years before a released species or strain can have any demonstrated effect.

Fly parasites appear to be significant in the natural mortality of both house and stablefly pupae on California dairies. While our experimental releases did increase parasitism of sentinel house fly pupae, the overall short-term increase in parasitism of field-collected stable or house fly pupae, or reduction in adult fly population levels, was negligible. Based on natural parasitism, Spalangia spp. probably inflict more fatalities than Muscidifurax spp., which made up the majority of released parasites in this study.

Jeffery A. Meyer is Extension Entomologist, Bradley A. Mullens is Associate Professor, and Tracy L. Cyr and Clare Stokes are Laboratory Assistants, all from the Department of Entomology, University of California, Riverside. 